\title{
Peripheral Artery Disease in Type 2 Diabetic Patients from the United Arab Emirates
}

Juma M Al-Kaabi ${ }^{1}$, Fatma Al Maskari ${ }^{*}$, Taoufik Zoubeidi ${ }^{3}$, Abdishakur Abdulle $^{1}$, Syed M Shah ${ }^{2}$, Paul Cragg $^{4}$, Bachar Afandi $^{4}$ and Abdul-Kader Souid $^{5}$

${ }^{1}$ Departments of Internal Medicine, UAE University, Al-Ain, Abu-Dhabi, UAE

${ }^{2}$ Institute of Public Health, College of Medicine and Health Sciences, UAE University, Al-Ain, Abu-Dhabi, UAE

${ }^{3}$ Department of Statistics, College of Business and Economics, UAE University, Al-Ain, Abu-Dhabi, UAE

${ }^{4}$ Diabetes Center, Tawam-Jones Hopkins Hospital, Al-Ain, Abu-Dhabi, UAE

${ }^{5}$ Pediatrics, College of Medicine and Health Sciences, UAE University, Al-Ain, Abu-Dhabi, UAE

*Corresponding author: Fatma Al-Maskari, Institute of Public Health, Director of Zayed Bin Sultan Center for Health Sciences. College of Medicine and Health Sciences, UAE University, PO Box 17666, Al-Ain, UAE, Tel: 0097137137452; Fax: 0097137672995; E-mail: fatma.am@uaeu.ac.ae

Rec date: May 11, 2014; Acc date: Jun 06, 2014; Pub date: Jun 10, 2014

Copyright: ( 2014 Maskari FA, et al. This is an open-access article distributed under the terms of the Creative Commons Attribution License, which permits unrestricted use, distribution, and reproduction in any medium, provided the original author and source are credited.

\begin{abstract}
Objectives: Peripheral Artery Disease (PAD) is common in patients with diabetes. Frequently, this complication is only recognized when the symptoms and signs are advanced. This study assessed its prevalence and associated risk factors in patients with type 2 diabetes mellitus who reside in the United Arab Emirates. The main purpose of the study was to identify potential disease modifiers that could be included in diabetic education programs.
\end{abstract}

Methods: This prospective, cross-sectional study assessed PAD in 394 patients with type 2 diabetes mellitus. Each patient was investigated by history, physical examination and measurements of the ankle-brachial index (ABI) by bidirectional doppler.

Results: Patients' mean $( \pm S D)$ age was $54( \pm 12)$ years and duration of diabetes $10( \pm 8)$ years. There were 264 females $(67 \%)$. HbA1c was $\geq 7 \%$ in $247(65 \%)$ patients, claudication present in $166(42 \%)$ patients, reduced capillary refill time in $69(17 \%)$ patients, retinopathy in $50(13 \%)$ patients, and absent pulse in $20(5 \%)$ patients. ABI was $\leq 1.0$ in $149(39 \%)$ patients (probable PAD) and $<0.9$ in $33(9 \%)$ patients (significant PAD). Current smoking [odds ratio $(\mathrm{OR})=3.9$; confidence intervals $(\mathrm{Cl})=1.5-10.3$; $p$-value $=0.007]$, percent $\mathrm{HbA1c}(\mathrm{OR}=3.4 ; \mathrm{Cl}=1.2-10.2 ; \mathrm{p}$-value $=0.028)$ and hypertension on examination $(\mathrm{OR}=1.6 ; \mathrm{Cl}=1.0-2.6 ; \mathrm{p}$-value=0.041) were significant predictors of $\mathrm{ABI} \leq 1.0$. Current smoking (OR=3.7; $\mathrm{Cl}=1.2-10.8 ; \mathrm{p}$-value=0.019) was significant predictor of $\mathrm{ABI}<0.9$.

Conclusions: These results confirm the deleterious effects of smoking on diabetes-association PAD. Thus, diabetic patients should be engaged in effective smoking prevention programs. Other modifiable interventions are controlling hyperglycemia and hypertension. Patients with abnormal $A B I$ (especially $<0.9$ ) should have stringent risk assessments and be started on an individualized risk-reduction program.

Keywords: Peripheral arterial disease; Type 2 diabetes mellitus; Prevalence; Risk factors; United Arab Emirates

\section{Introduction}

Type 2 diabetes mellitus, hypertension and dyslipidemia are highly prevalent in the United Arab Emirates (UAE) [1,2]. The hot climate, rapid urbanization, modernized lifestyle, suboptimal diets, smoking habits and physical inactivity are all expected to influence and contribute to the progression of diabetic complications in the region [3-9]. Most of these problems have not been adequately studied. Relevant knowledge of diabetic disease modifiers and patient education programs are also incomplete. Thus, local studies addressing the natural history of diabetes and prevention interventions are needed.

Atherosclerosis and Peripheral Artery Disease (PAD) are common in diabetic patients $[10,11]$. These serious problems are progressive and usually remain asymptomatic until the diabetes is in an advanced stage, which may be partially due to the associated diabetic neuropathy
[12]. The true prevalence of these disorders is unknown since different diagnostic criteria have been used in the published studies $[11,12]$.

The presence of PAD increases the risk of major cardiovascular events, such as stroke and myocardial infarction [13-15]. The PAD severity has been linked to patient's age, duration of diabetes, hyperglycemia and other factors, such as obesity, smoking, hypertension and dyslipidemia [11,12]. Clinically, a critical limb ischemia produces intermittent claudication, pain in the peripheries, foot ulcers and gangrene. The patient's physical signs include pulseless, proximal vascular bruits, hair loss, trophic nails, skin alternations, muscle atrophy, cold feet and pallor on limb elevation $[16,17]$.

The doppler pressure index [ankle-brachial index, (ABI)] has been used reliably in outpatient settings to screen for PAD [18]. There are no absolute diagnostic cutoffs for interpreting ABI [19]. ABI values of $\leq 1.0$ suggest probable artery disease and $<0.9$ suggest significant artery disease $[19,20]$. Other studies only used $A B I<0.9$ as a marker of $\mathrm{PAD}$ [11]. Non-invasive investigations also include magnetic 
resonance angiography, computerized tomography scan and measurements of foot temperature and hemoglobin-oxygen saturation $[11,21]$. The invasive diagnostic procedure is arteriography [20].

Diabetes-associated PAD has not been adequately investigated in the UAE. This study determined its prevalence and associated risk factors in patients with type 2 diabetes.

\section{Materials and Methods}

The study design (interviews, questionnaire, data collection and measurements) and patient population were previously described [22]. Briefly, this prospective, cross-sectional study enrolled 394 adults (264 females, 67\%) with type 2 diabetes from the Diabetes Center at Tawam-Johns Hopkins Hospital (Al Ain, Abu Dhabi) [22]. The study was approved by Al Ain Medical District Human Research Ethics Committee and informed consent was obtained from each patient. Inclusion criteria were adults with type 2 diabetes for at least 12 months. Exclusion criteria included known causes of vasculopathy, such as vasculitis and collagen vascular disease.

Assessment of peripheral arterial function was performed for each foot. The measurements included skin temperature, color, hair distribution, subcutaneous fat, capillary refill time and pulses in the dorsalis pedis and posterior tibial arteries. Blood pressure (systolic and phase- $\mathrm{V}$ diastolic) in the upper extremity was measured after $10 \mathrm{~min}$ resting, using validated electronic sphygmomanometers (Omron Hem 907, Omron Healthcare, Kyoto, Japan). Systolic blood pressure in the lower extremity was measured in the supine position by Huntleigh Multi Dopplex II Bi-Directional Doppler (Huntleigh Diabetic Foot Assessment Kit, Luton, UK). Systolic blood pressure was also measured at the right and left brachial, posterior tibial and dorsalis pedis arteries. For each side, the highest blood pressure reading in the posterior tibial and dorsalis pedis arteries was recorded. ABI was calculated for each side by dividing ipsilateral pedal arterial pressure over brachial arterial pressure. The lowest ABI was considered for each patient [19].

Eye examination was conducted by an ophthalmologist [22]. Dyslipidemia was defined as triglycerides $>1.7 \mathrm{mmol} / \mathrm{L}$, Low-density Lipoprotein (LDL) $>2.6 \mathrm{mmol} / \mathrm{L}$, or High-density Lipoprotein (HDL) $<1.0 \mathrm{mmol} / \mathrm{L}$ for males and $<1.3 \mathrm{mmol} / \mathrm{L}$ for females [23]. Hypertension was defined as systolic blood pressure $\geq 140 \mathrm{~mm} \mathrm{Hg}$ or diastolic blood pressure $\geq 90 \mathrm{~mm} \mathrm{Hg}$ [24].

The Statistical Package for Social Sciences (SPSS) software version 19.0 for Windows was used and logistic regression analysis identified independent predictors of neuropathy. A P-value $<0.05$ was significant. Simple logistic regression was used to investigate associations between risk factors and binary responses. Stepwise logistic and linear regression methods were used to identify better sets of predictors of binary and quantitative response variables, respectively.

\section{Results}

Characteristics of the patients are shown in Table 1; additional features are as previously described [22]. Significant numbers of patients had medical histories of dyslipidemia (73\%), hypertension (59\%), and lower extremity pain with walking (42\%). On examination, hypertension (38\%), abnormal gait (17\%), retinopathy (13\%), and impaired perfusion (reduced capillary refill time and absent peripheral pulses $17 \%$ ) were also frequent. On investigation, increased body fat percentage (90\%), dyslipidemia (63\%), and poor diabetic control (65\%; defined as $\mathrm{HbA1c} \geq 7 \%$ ) were common. Twenty patients (5\%) had absent dorsalis pedis or posterior tibial arterial pulse. The prevalence of $\mathrm{ABI} \leq 1.0$ (probably arterial disease) was $39 \%$ and $<0.9$ (significant arterial disease) was $9 \%$ (Table 1). Sixty-seven percent of the patients were on oral hypoglycemic agent and $29 \%$ were on insulin. There was no significant difference in the prevalence of PAD between the two groups $(\mathrm{p}=0.913)$.

\begin{tabular}{|l|l|l|l|}
\hline \multicolumn{2}{|l|}{ Male n=130 (\%) } & $\begin{array}{l}\text { Female n=264 } \\
(\%)\end{array}$ & $\begin{array}{l}\text { Total n=394 } \\
(\%)\end{array}$ \\
\hline \multicolumn{1}{|l|}{ History } & $102(78)$ & $187(71)$ & $289(73)$ \\
\hline Dyslipidemia & $72(55)$ & $162(61)$ & $234(59)$ \\
\hline High blood pressure & $48(37)$ & $118(45)$ & $166(42)$ \\
\hline Claudication heart & $19(18)$ & $15(6)$ & $34(9)$ \\
\hline $\begin{array}{l}\text { Ischemic } \\
\text { disease }\end{array}$ & $21(16)$ & $3(1)$ & $24(6)$ \\
\hline Currently smoking & $4(3)$ & $5(2)$ & $9(2)$ \\
\hline Stroke & &
\end{tabular}

Examination

\begin{tabular}{|l|l|l|l|}
\hline High blood pressurea & $41(33)$ & $102(40)$ & $143(38)$ \\
\hline Abnormal gait & & & \\
\hline Unsteady/ difficult & $18(18)$ & $23(11)$ & $41(11)$ \\
\hline Walking with aid & $8(8)$ & $10(5)$ & $18(5)$ \\
\hline On wheelchair & 0 & $3(1)$ & $3(1)$ \\
\hline$\downarrow$ Capillary refill time & & & \\
\hline Right & $34(27)$ & $35(13)$ & $69(17)$ \\
\hline Left & $31(34)$ & $35(16)$ & $66(16)$ \\
\hline Retinopathy & & & \\
\hline Background & $8(9)$ & $15(7)$ & $23(6)$ \\
\hline Pre-proliferative & $8(9)$ & $4(2)$ & $12(3)$ \\
\hline Maculopathy & $2(2)$ & $1(<1)$ & $3(<1)$ \\
\hline Proliferative & $5(6)$ & $5(2)$ & $10(3)$ \\
\hline Advance disease & $1(1)$ & $1(<1)$ & $2(<1)$ \\
\hline Absent pulseb & $6(5)$ & $14(6)$ & $20(5)$ \\
\hline nif & & & \\
\hline
\end{tabular}

\begin{tabular}{|c|c|c|c|}
\hline \multicolumn{4}{|l|}{ Investigation } \\
\hline $\begin{array}{l}\text { Increased body fat } \\
\text { percentaged }\end{array}$ & $90(76)$ & $241(97)$ & $331(90)$ \\
\hline Dyslipidemiac & $177(72)$ & $70(28)$ & $247(63)$ \\
\hline $\mathrm{HbA} 1 \mathrm{c}<7 \%$ & $39(33)$ & $91(35)$ & $130(35)$ \\
\hline $\mathrm{HbA} 1 \mathrm{c} \geq 7 \%$ & $81(67)$ & $166(65)$ & $247(65)$ \\
\hline \multicolumn{4}{|l|}{ Ankle-brachial index } \\
\hline Right ankle & $1.2 \pm 0.2$ & $1.1 \pm 0.2$ & $1.1 \pm 0.2$ \\
\hline
\end{tabular}


Page 3 of 6

\begin{tabular}{|l|l|l|l|}
\hline Left ankle & $1.2 \pm 0.2$ & $1.2 \pm 0.6$ & $1.2 \pm 0.5$ \\
\hline $\begin{array}{l}\text { Ankle-brachial index } \\
\text { categories }^{\mathrm{e}}\end{array}$ & & $148(57)$ & $231(60)$ \\
\hline $\begin{array}{l}\text { Probably no artery } \\
\text { disease }(1.0<\text { index } \\
\leq 1.4)\end{array}$ & $83(66)$ & $107(41)$ & $149(39)$ \\
\hline $\begin{array}{l}\text { Probable artery } \\
\text { disease (index } \leq 1.0)\end{array}$ & $42(34)$ & $22(9)$ & $33(9)$ \\
\hline $\begin{array}{l}\text { Significant artery } \\
\text { disease (index <0.9) }\end{array}$ & $11(9)$ & $5(2)$ & $5(1)$ \\
\hline $\begin{array}{l}\text { Probable artery } \\
\text { calcification (index } \\
>1.4)\end{array}$ & 0 & & \\
\hline
\end{tabular}

Values are number (percent) of patients or mean \pm SD. The percentages were calculated based on number of patients with available information.

aHigh blood pressure was defined as systolic $\geq 140$ or diastolic $\geq 90 \mathrm{~mm} \mathrm{Hg}$

${ }^{b}$ Absent posterior tibial or dorsalis pedis arterial pulse on either side.

'Dyslipidemia was defined as triglycerides $>150 \mathrm{mg} / \mathrm{dl}(1.7 \mathrm{mmol} / \mathrm{l})$, low density lipoprotein $(\mathrm{LDL})>100 \mathrm{mg} / \mathrm{dl}(2.6 \mathrm{mmol} / \mathrm{L})$ or $\mathrm{HDL}<40 \mathrm{mg} / \mathrm{dl}(1.0 \mathrm{mmol} / \mathrm{l})$ in $\mathrm{men}$ and $<50 \mathrm{mg} / \mathrm{dl}(1.3 \mathrm{mmol} / \mathrm{l})$ in women.

dAbnormal fat composition was as $>23 \%$ in males and $>27 \%$ in females.

eLowest determination in each patient; $p$-value between the genders $=0.071$ (Mann-Whitney U test). The categories are based on Al-Qaisi et al., 2009.

Table 1: Variables relevant to peripheral arterial disease in the studied patients

Based on $\mathrm{ABI} \leq 1.0$, the prevalence of PAD in males was $34 \%$ and females $41 \%$ ( $\mathrm{p}=0.071$ ). Based on $\mathrm{ABI} \leq 0.9$, the prevalence of PAD in males and females was $9 \%$ (Table 1). Table 2 shows simple logistic regression analyses of abnormal ABI vs. a few selected parameters. Current smoking $(\mathrm{p}=0.002)$ and history of claudication $(\mathrm{p}=0.005)$ were significant predictors of $\mathrm{ABI} \leq 1.0$. Current smoking was the only significant predictor of $A B I<0.9(p=0.001)$.

Table 3 (multivariable logistic regression analyses) shows subset of significant predictors of the odds of abnormal ABI vs. predictors. Predictors for $A B I \leq 1.0$ were current smoking ( $\mathrm{p}=0.007$ ), percent HbAlc $(\mathrm{p}=0.028)$, and increased blood pressure $(\mathrm{p}=0.041)$. Current smoking was associated with 3.9 time increase in the odds for ABI $\leq 1.0$. A $1 \%$ increase in $\mathrm{HbAlc}$ was associated with 3.4 times increase in the odds for $\mathrm{ABI} \leq 1.0$. Hypertension on examination was associated with 1.6 times increase in the odds for $\mathrm{ABI} \leq 1.0$ (Table 3). Predictor for $\mathrm{ABI}<0.9$ was only current smoking $(\mathrm{p}=0.019)$, Table 3 .

The distribution of ABI was bimodal. Mixture analysis was performed using PC-Normix program http://www.alumni.caltech.edu/ $\sim$ wolfe/ normix.htm. This statistical program searches for clusters with normal distributions within a mixed population $(\mathrm{p}<0.05)$ [25]. The results demonstrated two ABI clusters (Figure 1).

\begin{tabular}{|l|l|l|l|l|}
\hline & Coefficient & $\mathbf{p}$-value & OR & $\mathbf{9 5 \%} \mathbf{C l}$ for OR \\
\hline $\begin{array}{l}\text { Current smoking (ref. } \\
\text { = no) }\end{array}$ & 1.42 & 0.002 & 4.12 & $1.67-10.19$ \\
\hline $\begin{array}{l}\text { Claudication } \\
\text { (ref. }=\text { no) }\end{array}$ & 0.62 & 0.005 & 1.85 & $1.21-2.84$ \\
\hline
\end{tabular}

\begin{tabular}{|c|c|c|c|c|}
\hline $\begin{array}{l}\text { Past smoking } \\
\text { (ref. }=\text { no) }\end{array}$ & 0.56 & 0.106 & 1.75 & $0.89-3.45$ \\
\hline $\begin{array}{l}\begin{array}{l}\text { Abnormal body } \\
\text { percentage } \\
\text { normal) }\end{array} \text { (ref. } \quad= \\
\end{array}$ & 0.39 & 0.268 & 1.48 & $0.74-2.96$ \\
\hline $\begin{array}{l}\text { Leg/ foot burning pain } \\
\text { (ref. = no) }\end{array}$ & 0.37 & 0.101 & 1.41 & $0.95-2.14$ \\
\hline $\begin{array}{l}\text { Male gender } \\
\text { (ref. = female) }\end{array}$ & 0.36 & 0.118 & 1.43 & $0.91-2.23$ \\
\hline $\begin{array}{l}\mathrm{LDL}>2.5 \mathrm{mmol} / \mathrm{L} \text { (ref. } \\
=\leq 2.5 \text { ) }\end{array}$ & 0.27 & 0.210 & 1.31 & $0.85-2.02$ \\
\hline $\begin{array}{l}\text { Triglycerides:HDL } \\
\text { ratio }\end{array}$ & 0.25 & 0.105 & 1.29 & $0.95-1.75$ \\
\hline $\begin{array}{l}\text { Hypertension (ref. }= \\
\text { no) }\end{array}$ & 0.19 & 0.380 & 1.21 & $0.79-1.85$ \\
\hline $\begin{array}{l}\text { Urinary } \\
\text { albumin:creatinine } \\
\text { ratio }(\mathrm{mg} / \mathrm{mmol})\end{array}$ & 0.17 & 0.487 & 1.19 & $0.73-1.92$ \\
\hline $\begin{array}{l}\uparrow \text { Triglycerides (ref. }= \\
\text { normal) }\end{array}$ & 0.15 & 0.566 & 1.16 & $0.70-1.91$ \\
\hline $\begin{array}{l}\text { Leg pain with walking } \\
\text { (ref. = no) }\end{array}$ & 0.11 & 0.623 & 1.11 & $0.73-1.69$ \\
\hline Percent HbA1c & 0.09 & 0.105 & 1.09 & $0.98-1.22$ \\
\hline $\begin{array}{l}\mathrm{HbA} 1 \mathrm{c} \quad \geq 7 \% \quad \text { (ref. }= \\
<7 \%)\end{array}$ & 0.04 & 0.878 & 1.04 & $0.67-1.61$ \\
\hline Age (yr) & 0.01 & 0.350 & 1.01 & $0.99-1.03$ \\
\hline Duration of diabetes & 0.001 & 0.386 & 1.00 & $0.99-1.003$ \\
\hline $\begin{array}{l}\text { Walking for purpose of } \\
\text { exercise (ref. = no) }\end{array}$ & -0.38 & 0.084 & 0.69 & $0.46-1.05$ \\
\hline $\begin{array}{l}\mathrm{HDL}<1.0 \mathrm{mmol} / \mathrm{L} \text { (ref. } \\
=\geq 1.0)\end{array}$ & -0.34 & 0.111 & 0.71 & $0.47-1.08$ \\
\hline $\begin{array}{l}\downarrow \text { Capillary refill time } \\
\text { (ref. }=\text { normal) }\end{array}$ & -0.24 & 0.707 & 0.79 & $0.23-2.73$ \\
\hline $\begin{array}{l}\text { Pulse not felt (ref. }= \\
\text { normal pulse) }\end{array}$ & -0.09 & 0.831 & 0.91 & $0.39-2.14$ \\
\hline Retinopathy (ref. = no) & -0.02 & 0.959 & 0.98 & $0.53-1.82$ \\
\hline \multicolumn{5}{|c|}{ Caseness represented by ankle-brachial index $\leq 1.0 \quad(n=149)$} \\
\hline
\end{tabular}

Table 2: Simple logistic regression of abnormal ankle-brachial index vs. selected predictors

\begin{tabular}{|l|l|l|l|l|l|}
\hline & Coefficient & OR & $\begin{array}{l}95 \% \text { Cl for } \\
\text { OR }\end{array}$ & p-value \\
\hline \multicolumn{5}{|c|}{ Ankle-brachial index $\leq 1.0(n=149)^{\mathrm{a}}$} \\
\hline $\begin{array}{l}\text { Current smoking } \\
\text { (ref. = no) }\end{array}$ & 1.35 & 3.9 & $1.5-10.3$ & 0.007 \\
\hline HbA1c (\%) & 1.23 & 3.4 & $1.2-10.2$ & 0.028 \\
\hline
\end{tabular}




\begin{tabular}{|c|c|c|c|c|}
\hline $\begin{array}{l}\uparrow \text { Blood pressure (on } \\
\text { examination) } \\
\text { (ref. = no) }\end{array}$ & 0.49 & 1.6 & $1.0-2.6$ & 0.041 \\
\hline \multicolumn{5}{|c|}{ Ankle-brachial index $<0.9(n=33)^{b}$} \\
\hline $\begin{array}{l}\text { Current smoking } \\
\text { (ref. }=\text { no) }\end{array}$ & 1.30 & 3.7 & $1.2-10.8$ & 0.019 \\
\hline \multicolumn{5}{|c|}{$\begin{array}{l}\text { aLikelihood ratio test of model significance: } p \text {-value }<0.001 \text { (Nagelkerke } R^{2}= \\
0.102 \text { ). }\end{array}$} \\
\hline \multicolumn{5}{|c|}{$\begin{array}{l}\text { bLikelihood ratio test of model significance: } p \text {-value }=0.033 \text { (Nagelkerke } R^{2}= \\
0.030 \text { ). }\end{array}$} \\
\hline \multicolumn{5}{|c|}{ OR: odds ratio; $\mathrm{Cl}$ : confidence interval; ref: reference category } \\
\hline \multicolumn{5}{|c|}{$\begin{array}{l}\text { Variables that were dropped out of the multivariable logistic regression using the } \\
\text { stepwise-backward elimination method were age, leg pain with walking, HDL } \\
\text { LDL and Michigan-sign score. }\end{array}$} \\
\hline
\end{tabular}

Table 3: Subset of significant predictors of the odds of abnormal anklebrachial index vs. selected predictors

\section{Discussion}

This study was the first in UAE to use ABI to screen for PAD in patients with type 2 diabetes. The probability distribution of $A B I$ in the studied population is shown in Figure 1. The prevalence of significant $\mathrm{PAD}(\mathrm{ABI}<0.9)$ was $9 \%$ and probable $\mathrm{PAD}(\mathrm{ABI} \leq 1.0)$ was $39 \%$ (Table 1). Previous studies in the UAE used pulse deficits (reduced/ absent) and showed a PAD prevalence of $11-12 \%[3,9]$.

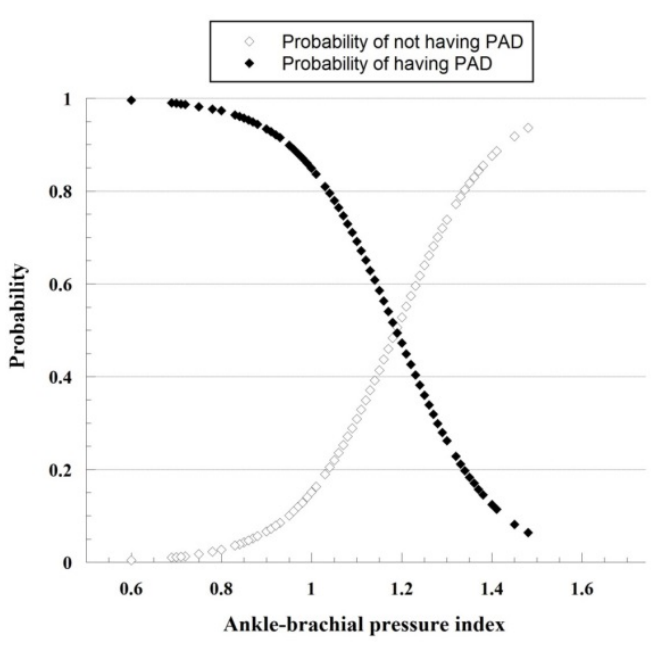

Figure 1: Mixture analysis; (PC-Normix program www.alumni.caltech.edu/ wolfe/normix.htm) probabilities of two ABI clusters in the studied population

A cross sectional study in primary health care facility from Saudi Arabia found $\sim 12 \%$ of diabetic patients had $\mathrm{ABI}<0.9$, and over $90 \%$ of these patients were asymptomatic [26]. In South Asia, the prevalence of $\mathrm{ABI}<0.9$ was $4-9 \%$ [27-29]. In a large Asian study (Korea, China, Taiwan, Hong Kong, Indonesia, Thailand and the Philippines), the prevalence of $\mathrm{ABI}<0.9$ was about $18 \%$ [30].

This study hypothesized that PAD is common because of frequent risk factors for atherosclerosis in our diabetic patients (smoking, hypertension, poor diabetic control, obesity, physical inactivity, etc.).
Current smoking, increased HbAlc and hypertension (on examination) were independent risk factors for PAD (Table 3). PAD was 3.9 times higher in smokers (Table 3 ). The majority of published studies show a high incidence of PAD in smokers. In one study, smokers with PAD were twice as likely to undergo lower limb amputation compared to non-smokers with PAD [17]. Smoking is thought to promote atherosclerosis by increasing LDL oxidation and augmenting endothelial dysfunction (by reducing in nitric oxidedependent vasodilatation) [31,32].

As in this study, the severity of hyperglycemia has frequently been shown to increase PAD [33]. Hyperglycemia is linked to the pathogenesis of atherosclerosis via the following three major mechanisms: advanced glycated end products, oxidative stress and protein kinase C activation [34]. There is no conclusive evidence, however, to suggest that optimal glycemic control lowers the risk of PAD in type 2 diabetic patients.

The finding that hypertension is an independent risk factor for PAD (Table 3) is also consistent with published literature. For example, Framingham studies showed the risk of developing PAD in hypertensive patients was twice that of normotensive patients [10,35].

Seventy-three percent of our patients had medical history of dyslipidemia (Table 1). This high prevalence may explain the insignificant associations between lipid profile and PAD in the studied population (Table 2). In other studies, increased LDL was shown to be an independent predictor of PAD [36]. In the Framingham Heart Study, elevated cholesterol was an important risk factor of claudication $[10,35]$.

Patient symptoms do not correlate well with ABI, emphasizing the need for screening of all patients with suspected PAD [37]. In clinical practice, $\mathrm{PAD}$ is under-diagnosed, particularly in diabetic patients due to their being asymptomatic until disease reaches an advanced stage, poor reporting of symptoms and loss of pain perception due to a coexisting neuropathy. In one study, PAD was found to be seven times more common in diabetic patients than none diabetic patients; PAD was also found to be asymptomatic until advanced stages [11]. It is worth noting that absence of peripheral pulses on palpation is not always diagnostic of arterial disease, since the dorsalis pedis pulse could be absent congenitally in $10-15 \%$ of the population [38].

Patients with abnormal ABI (especially <0.9) should have stringent risk assessments and started on individualized risk-reduction program. Follow-up and repetitive measurements are necessary. Further assessments may include magnetic resonance angiography and computerized tomography angiography scan.

Figure 1 shows the Mixture analysis model for probability of having $\mathrm{PAD}$ for any given value of ABI. This approximation was based on the PC-Normix Program, which identified two clusters of normal distributions within our studied patients $(p<0.05)$ [25]. The model predicted a probability of PAD of about $80 \%$ for ABI of 1.0 .

The study limitations included lack of confirmatory tests, such as magnetic resonance angiography, computerized tomography scan and invasive arteriography. The study is based on a single large diabetes center and thus the prevalence of PAD cannot be generalized for the whole UAE. Multicenter study is needed. It is a cross sectional study and thus did not establish causality. Follow up studies are needed to assess the progression of PAD with various risk factors and outcome of using different classes of medications. 
Sixteen percent of the approached patients declined to participate [22]. This problem might have produced a selection bias, since symptomatic patients were more likely to be included than asymptomatic patients.

\section{Conclusions}

The important finding is this study is that current smoking is most significant predictor of PAD ( $\mathrm{p}=0.007)$. Other modifiable risk factors include hyperglycemia and hypertension. The high prevalence of PAD in our studied diabetic population points out to the need for routine screening and structured managements. These tasks require active measures that include patient education, risk assessment, and timely intervention.

\section{Acknowledgments}

This work was supported by a fund from the College of Medicine and Health Sciences, United Arab Emirates University. The authors are in debt to the staff of Tawam Hospital for their invaluable support.

\section{References}

1. International Diabetes Federation (2013) IDF Diabetes Atlas, 6th edn. Brussels, Belgium: International Diabetes Federation.

2. Hajat C, Harrison O, Al Siksek Z (2012) Weqaya: a population-wide cardiovascular screening program in Abu Dhabi, United Arab Emirates. Am J Public Health 102: 909-914.

3. Al-Maskari F, El-Sadig M (2007) Prevalence of risk factors for diabetic foot complications. BMC Fam Pract 8: 59.

4. Al-Salamah SM (2005) General surgical problems encountered in the Hajj pilgrims. Saudi Med J 26: 1055-1057.

5. Ahmed AA (2010) Epidemiology of diabetes mellitus and diabetic foot problems in Saudi Arabia. Av Diabetol 26: 29-35.

6. Al-Wahbi AM (2006) The diabetic foot. In the Arab world. Saudi Med J 27: 147-153.

7. Al-Mahroos F, Al-Roomi K (2007) Diabetic neuropathy, foot ulceration, peripheral vascular disease and potential risk factors among patients with diabetes in Bahrain: a nationwide primary care diabetes clinic-based study. Ann Saudi Med 27: 25-31.

8. Elsharawy MA, Hassan K, Alawad N, Kredees A, Almulhim A (2012) Screening of diabetic foot in surgical inpatients: a hospital-based study in saudi arabia. Int J Angiol 21: 213-216.

9. Saadi H, Carruthers SG, Nagelkerke N, Al-Maskari F, Afandi B, et al. (2007) Prevalence of diabetes mellitus and its complications in a population-based sample in Al Ain, United Arab Emirates. Diabetes Res Clin Pract 78: 369-377.

10. Kannel WB, McGee DL (1985) Update on some epidemiologic features of intermittent claudication: the Framingham Study. J Am Geriatr Soc 33: 13-18.

11. Jude EB, Eleftheriadou I, Tentolouris N (2010) Peripheral arterial disease in diabetes--a review. Diabet Med 27: 4-14.

12. American Diabetes Association (2003) Peripheral arterial disease in people with diabetes. Diabetes Care 26: 3333-3341.

13. Valentijn TM, Stolker RJ (2012) Lessons from the REACH Registry in Europe. Curr Vasc Pharmacol 10: 725-727.

14. Mukherjee D, Eagle K (2010) The importance of early diagnosis and treatment in peripheral arterial disease: insights from the PARTNERS and REACH registries. Curr Vasc Pharmacol 8: 293-300.

15. Golomb BA, Dang TT, Criqui MH (2006) Peripheral arterial disease: morbidity and mortality implications. Circulation 114: 688-699.

16. Mohler ER 3rd (2003) Peripheral arterial disease: identification and implications. Arch Intern Med 163: 2306-2314.
17. Dormandy JA, Rutherford RB (2000) Management of peripheral arterial disease (PAD). TASC Working Group. TransAtlantic Inter-Society Consensus (TASC). J Vasc Surg 31: S1-1S296.

18. Kim ES, Wattanakit K, Gornik HL (2012) Using the ankle-brachial index to diagnose peripheral artery disease and assess cardiovascular risk. Cleve Clin J Med 79: 651-661.

19. Al-Qaisi M, Nott DM, King DH, Kaddoura S (2009) Ankle brachial pressure index (ABPI): An update for practitioners. Vasc Health Risk Manag 5: 833-841.

20. European Stroke Organisation, Tendera M, Aboyans V, Bartelink ML, Baumgartner I, et al. (2011) ESC Guidelines on the diagnosis and treatment of peripheral artery diseases: Document covering atherosclerotic disease of extracranial carotid and vertebral, mesenteric, renal, upper and lower extremity arteries: the Task Force on the Diagnosis and Treatment of Peripheral Artery Diseases of the European Society of Cardiology (ESC). Eur Heart J 32: 2851-2906.

21. Scottish Intercollegiate Guidelines Network (2006) Diagnosis and management of peripheral arterial Disease, A national clinical guideline.

22. Al-Kaabi JM, Al-Maskari F, Zoubeidi T, Abdulle A, Shah SM et al (2014). Prevalence and Determinants of Peripheral Neuropathy in Patients with Type 2 Diabetes Attending a Tertiary Care Center in the United Arab Emirates. J Diabetes Metab 5: 346.

23. Haffner SM; American Diabetes Association (2004) Dyslipidemia management in adults with diabetes. Diabetes Care 27 Suppl 1: S68-71.

24. American Diabetes Association (2014) Standards of medical care in diabetes--2014. Diabetes Care 37 Suppl 1: S14-80.

25. Wolfe JH (1970) Pattern clustering by multivariate mixture analysis. Multivariate Behavior Res 5: 329-350.

26. Al-Sheikh SO, Aljabri BA, Al-Ansary LA, Al-Khayal LA, Al-Salman MM, et al. (2007) Prevalence of and risk factors for peripheral arterial disease in Saudi Arabia. A pilot cross-sectional study. Saudi Med J 28: 412-414.

27. Viswanathan V, Thomas N, Tandon N, Asirvatham A, Rajasekar S, et al. (2005) Profile of diabetic foot complications and its associated complications--a multicentric study from India. J Assoc Physicians India 53: 933-936.

28. Chaturvedi N, Abbott CA, Whalley A, Widdows P, Leggetter SY, et al (2002) Risk of diabetes-related amputation in South Asians vs. Europeans in the UK. Diabet Med 19: 99-104.

29. Mohan V, Premalatha G, Sastry NG (1995) Peripheral vascular disease in non-insulin-dependent diabetes mellitus in south India. Diabetes Res Clin Pract 27: 235-240.

30. Rhee SY, Guan H, Liu ZM, Cheng SW, Waspadji S, et al. (2007) Multicountry study on the prevalence and clinical features of peripheral arterial disease in Asian type 2 diabetes patients at high risk of atherosclerosis. Diabetes Res Clin Pract 76: 82-92.

31. Sanderson KJ, van Rij AM, Wade CR, Sutherland WH (1995) Lipid peroxidation of circulating low density lipoproteins with age, smoking and in peripheral vascular disease. Atherosclerosis 118: 45-51.

32. Celermajer DS, Sorensen KE, Georgakopoulos D, Bull C, Thomas O et al (1993). Cigarette smoking is associated with dose-related and potentially reversible impairment of endothelium-dependent dilation in healthy young adults. Circulation 88: 2149-2155.

33. Adler AI, Stevens RJ, Neil A, Stratton IM, Boulton AJ, et al. (2002) UKPDS 59: hyperglycemia and other potentially modifiable risk factors for peripheral vascular disease in type 2 diabetes. Diabetes Care 25: 894-899.

34. Brownlee M (2005) The pathobiology of diabetic complications: a unifying mechanism. Diabetes 54: 1615-1625.

35. Murabito JM, D'Agostino RB, Silbershatz H, Wilson WF (1997) Intermittent claudication. A risk profile from The Framingham Heart Study. Circulation 96: 44-49.

36. Kownator S, Cambou JP, Cacoub P, Léger P, Luizy F, et al. (2009) Prevalence of unknown peripheral arterial disease in patients with coronary artery disease: data in primary care from the IPSILON study. Arch Cardiovasc Dis 102: 625-631. 
Citation: $\quad$ Al-Kaabi JM, Al Maskari F, Zoubeidi T, Abdulle A, Shah SM, et al. (2014) Peripheral Artery Disease in Type 2 Diabetic Patients from the United Arab Emirates. J Diabetes Metab 5: 388. doi:10.4172/2155-6156.1000388

Page 6 of 6

37. Lin JS, Olson CM, Johnson ES, Whitlock EP (2013) The ankle-brachia index for peripheral artery disease screening and cardiovascular disease prediction among asymptomatic adults: a systematic evidence review for the U.S. Preventive Services Task Force. Ann Intern Med; 159: 333-341.
38. Feigelson HS, Criqui MH, Fronek A, Langer RD, Molgaard CA (1994) Screening for peripheral arterial disease: the sensitivity, specificity, and predictive value of noninvasive tests in a defined population. Am J Epidemiol 140: 526-534. 